\section{Food environment, income and obesity: a multilevel analysis of a reality of women in Southern Brazil}

\author{
Ambiente alimentar, renda e obesidade: \\ uma análise multinível da realidade de \\ mulheres no Sul do Brasil
}

Entorno alimentario, renta y obesidad: un análisis multinivel de la realidad de mujeres en el Sur de Brasil
Vanessa Backes 1,2

Fernanda Bairros 1

Cristina Borges Cafruni 1

Steven Cummins 3

Martine Shareck 3

Kate Mason 3

Juvenal Soares Dias-da-Costa 1

Maria Teresa Anselmo Olinto 1

doi: 10.1590/0102-311X00144618

\begin{abstract}
The objective of this study was to explore relationships between the neighborhood food environment and obesity in urban women living in São Leopoldo, Rio Grande do Sul State, Brazil. A cross-sectional survey was carried out. This study was conducted with 1,096 women. Structured interviews were conducted using a standard pre-tested questionnaire. Obesity was defined as body mass index $(B M I) \geq 30 \mathrm{~kg} / \mathrm{m}^{2}$. Circular buffers of $400 \mathrm{~m}$ in radius were created based on the centroid of the women's houses who participated, in the 45 census tracts inhabited by them. Neighborhood food establishments were identified through systematic survey of all streets in the study areas and geographical coordinates of shops were collected. Establishments were evaluated using the NEMS tool. The prevalence of obesity was 33\% among the women participants. After adjusting for individual variables, supermarkets and healthy food establishments were positively associated with obesity, $P R=1.05$ (95\%CI: 1.01-1.10), PR = 1.02 (95\%CI: $1.00-1.04)$, respectively, while mean buffer income was negatively associated, $P R=0.64$ (95\% CI: 0.490.83). Neighborhood food environment factors were associated with obesity even after controlled for individual variables, as socioeconomic variables, behavioral and food purchase.
\end{abstract}

Feeding; Obesity; Women

\author{
Correspondence \\ V. Backes \\ Rua Padre Luiz Gonzaga Jaeger 570, São Leopoldo, RS \\ 93022-250, Brasil. \\ nessabck@yahoo.com.br \\ 1 Universidade do Vale do Rio dos Sinos, São Leopoldo, Brasil. \\ 2 Prefeitura Municipal de São Leopoldo, São Leopoldo, Brasil. \\ 3 London School of Hygiene es Tropical Medicine, London, U.K.
}




\section{Introduction}

The prevalence of obesity has increased in the world in the last decades ${ }^{1}$. The growing increase in obesity is influenced by contextual issues, since lifestyle, diet and physical activity practices are influenced by economic growth 2,3,4,5,6,7,8. There is much evidence that family and contextual income influence obesity 9,10,11. In Brazil, low-income women have a higher prevalence of obesity when compared to high-income women but the causal relationship is not well established 12,13.

Interventions focused on people changing their eating behaviors to improve their nutritional status have had limited success 2 . Although the individual approach is necessary, it is not sufficient and changing the contextual determinants of healthy eating also needs to be considered.

Recently, the interest in the potential impact of the neighborhood on individual health and healthy diet components has increased. The food environment refers to physical, economic, political and sociocultural characteristics, opportunities and conditions that influence food behaviors 14,15 . The food environment can influence food acquisition practices and whether people make healthy food choices or not, because besides being influenced by the individuals' preferences and knowledge about food, food behavior is influenced by the location of food stores and the price of available foods $15,16,17,18,19,20,21,22$. These characteristics, among other factors, may lead to the development of obesity and related conditions 23,24 .

Types of food stores have been considered proxies for healthy or unhealthy diets. In Brazil, supermarkets offer many different types of ultraprocessed foods, but, on the other side, they also offer healthy foods to consumers 18,25 . This is different from grocery stores which predominantly sell ultraprocessed foods and few healthy foods, fruits and vegetables 26 . A Brazilian study with children shows that the availability of natural foods was associated with an increase of these foods consumption and a decrease of ultraprocessed food consumption ${ }^{22}$. In addition to the quality of food available in the neighborhood, the density of establishments is also a factor associated with nutritional status: in neighborhoods where there is a high diversity of food stores, residents tend to have a normal nutritional status 27,28 .

Neighborhood social disadvantage is another contextual characteristic related to obesity. Socially disadvantaged neighborhoods tend to have a lower availability of healthy foods when compared to more advantaged neighborhoods 29,30,31,32,33,34,35,36,37. Menezes et al. 35, when evaluated Brazilian adults found that average consumption of fruits and vegetables was higher in neighbourhoods with higher income and concentration of food stores. Furthermore, studies exploring the relationship between the food environment and obesity suggest that higher access to healthy food is associated with better diet quality and lower rates of obesity $26,29,38,39,40$.

Although the relationship between the food environment and obesity has been studied in developed countries 41,42, few studies have focused on low and middle-income countries 28,42,43. The objective of this study was to explore the relationship between the neighborhood food environment and obesity in women living in São Leopoldo, Rio Grande do Sul State, Brazil. We also assessed if relationships differed by income group. We hypothesized that living in a neighborhood with more supermarket and healthy food stores would protect residents from being obese, while living in areas with more grocery stores and convenience stores would increase the risk of being obese.

\section{Materials and methods}

This study was part of the larger project Living Conditions and Health of Adult Women: A Populationbased Study in Vale do Rio dos Sinos - Evaluation after 10 Years, Rio Grande do Sul, Brazil. The present investigation had two stages of data collection. First, a cross-sectional population-based study of a representative sample of 1,096 women living in the urban area of São Leopoldo. Second, gathering information on the neighborhoods in which participants resided. The county of São Leopoldo is located in the Sinos River Valley, Porto Alegre Metropolitan Area, and in 2010, it had a population of 214,087 inhabitants 44 . 


\section{Individual-level data collection}

Individual data were collected by structured interviews with women aged 20-69 years using a standardized and pre-tested questionnaire, validated to ensure questions were understood correctly. A pilot study in a census tract, not included in the final sample, was conducted to test the methods and logistics of the research and if the questionnaire was adequate. The sample size for the overall study was estimated from the different outcomes predicted in this project, choosing the one with the largest sample size required to perform a cross-sectional analysis. Based on sample size calculations for identifying a risk ratio of 2.0 for a $95 \%$ confidence level and statistical power of $80 \%$, with the ratio of 1 unexposed to 2 exposed, a total of 1,335 households were required to be visited in 45 census tracts. Cluster-based sampling was carried out, where 45 census tracts were drawn among the 371 in the urban area of São Leopoldo, using the "Value of the monthly nominal income of persons aged 10 years and over (with or without yield)" 44. For each census tract, 36 households were selected. Pregnant women were excluded from the study.

\section{Environmental-level data collection}

We evaluated the neighborhood environment (stores, schools, parks, food stores, among others) of the 45 census tracts in which participants resided at the same period as when the individual-level data were collected in 2015. The geographical coordinates (latitude and longitude) of participants' residences were collected with GPS units (Etrex/Hcx/Garmin) when first visited for the individuallevel data collection.

For each census tract, the centroid of the participants' residential locations was identified and used as an anchor to define a $400 \mathrm{~m}$ radius buffer. Circular buffers have previously been used to geographically approximate individuals' neighborhood $45,46,47,48$. A $400 \mathrm{~m}$ buffer was used since $400 \mathrm{~m}$ is a reasonable distance for an individual to walk to a point of interest 49 .

Researchers visited each buffer on foot to identify food stores and record their geographical coordinates by GPS. After the identification, formal and informal food stores were visited and assessed using an adapted version of the Nutrition Environment Measure - Stores (NEMS) tool 50,51. This questionnaire evaluates the in-store availability and price of food, as well as the quality of fruits and vegetables available. The questionnaire allowed to distinguish three food groups: healthy, intermediate and unhealthy, according to the nutritional composition and the price of the food. Unhealthy foods received a negative score and healthy foods received a positive score. For the analyses, the stores considered healthy were those that had an overall positive score, meaning that they carried more healthy than unhealthy foods.

\section{Measures}

\section{- Individual variables}

The obesity outcome was evaluated at the individual level by means of the body mass index (BMI: ratio of weight in kilograms to the square of the height in meters). Women with a BMI $\geq 30 \mathrm{~kg} / \mathrm{m}^{2}$ were considered obese 52 .

Demographic variables included age (in 10-year groupings), skin color (self-identified and categorized as white vs. non-white), and marital status (married vs. unmarried, separated or widowed). Individual socioeconomic variables were household income (in tertiles), years of schooling (continuous), and paid employment status (in paid employment vs. not). A food frequency questionnaire (FFQ) was used to assess the daily consumption of fruits, vegetables, and sugary drinks. Women reported how many days per week or month they consumed each of 14 types of fruits, 11 types of vegetables and 2 types of sugar drinks in the 3 months prior to interview. In each category (fruits, vegetables and sugar drinks), items were summed to obtain the intake frequency per day 53 . Food frequency questionnaires may refer to different timeframes depending on the research objective 54 . In our study, we assessed intake 3-months prior to interview in order for the timing of the food intake and food environment measurements to be consistent. 
Variables describing food purchasing practices included: the number of stores that women accessed to buy each of eight food items (rice, beans, milk, bread, meat, fruit, vegetables and industrialized products) and the number of food establishments that women accessed in the neighborhood where they lived (a subjective definition of neighborhood), both analyzed as continuous variables and transport mode used to purchase food (on foot and/or bicycle, car, motorcycle and/or bus).

\section{- Contextual variables}

Four variables related to the food environment were studied, namely the number of supermarkets, grocery stores (local food store), convenience stores (shop at gas station), and healthy stores (categorized through the NEMS score) in each of the 45 buffers.

The mean buffer-level income was also used to explore potential moderation of the association between food store availability and obesity. The mean buffer-level income was defined as the mean household income of the census tracts, calculated using official census data 44 . In cases where buffers overlapped multiple census tracts, income information for the different census tract was combined.

Data collection stages had quality control. First, we administered a control questionnaire, including variables that should not change over a short time frame, to $10 \%$ of the sample, 2 months after their first interview. This was done by telephone or home visits. Different interviewers also reviewed $20 \%$ of the buffers 15 to 40 days after the first environmental-level data collection by recording the coordinates of all food stores found. The intraclass correlation coefficient (ICC) was calculated and the value found for the food stores was 0.81 which is considered excellent 55 .

\section{- Statistical analyses}

Data entry was performed in EpiData, version 3.1 (http://www.epidata.dk/). Double entry and subsequent comparison allowed to eliminate errors due to typing mistakes. Data analysis was conducted with Stata, version 12.0 (https://www.stata.com). We used Poisson regression with robust standard error to estimate crude and adjusted prevalence ratios (PR) and 95\% confidence intervals (95\%CI) controlling for the hierarchical study design (with 8 to 37 participants in each buffer) 56. Poisson regression was used due to the high prevalence of the outcome in the sample 57.

We first assessed the association between individual variables only, and then examined the relationship between obesity and food environment variables. Variables that were significantly associated with the outcome at a 0.05 significance level were considered possible confounding factors and included in the adjusted models. Multilevel analyses for each of the food environment variables and neighborhood-level income controlled for sociodemographic and economic characteristics, variables related to the purchase of food, and for fruit and vegetable intake. We tested the interaction between income and types of food stores and all presented $\mathrm{p}<0.05$. Therefore, we used Poisson analysis to assess the relationship between the availability of specific types of food stores and obesity stratified by family income.

The research protocol was approved by the Ethics Research Committee of the University of Vale dos Sinos River (UNISINOS; CEP 653,394). Participants provided informed consent prior to data collection and were guaranteed complete confidentiality.

\section{Results}

From the 1,281 women in the full study sample, 153 refused to participate, 4 could not provide weight and height measurements, and 28 resided outside the buffer defined for their neighborhood. These were excluded from the analyses for a final analytical sample of 1,096 women. Despite exclusions, the analytical sample was representative, in terms of its demographic characteristics, to IBGE (Brazilian Institute of Geography and Statistics) data.

Table 1 shows socioeconomic, demographic and food purchase characteristics for the complete sample and according to obesity status. Women in the sample were white skin color (74.3\%), married or in union (63.8\%), aged 50 years or more (34.6\%), had completed higher education (41.5\%) and 
Table 1

Sociooeconomic, demographic and food purchase characteristics of the total sample and according to obesity ( $n=1,096)$. São Leopoldo, Rio Grande do Sul State, Brazil, 2015.

\begin{tabular}{|c|c|c|c|c|c|c|}
\hline \multirow[t]{2}{*}{ Variables } & \multirow[t]{2}{*}{$\mathbf{n}$} & \multirow[t]{2}{*}{$\%$} & \multicolumn{4}{|c|}{ Obesity } \\
\hline & & & $\%$ & PR & $95 \% \mathrm{Cl}$ & p-value \\
\hline Age (years) & & & & & & $<0.001$ \\
\hline $20-29$ & 211 & 19.3 & 12.2 & - & - & \\
\hline $30-39$ & 238 & 21.7 & 21.0 & 1.54 & $1.11-2.13$ & \\
\hline $40-49$ & 267 & 24.4 & 24.3 & 1.59 & $1.16-2.18$ & \\
\hline$\geq 50$ & 380 & 34.6 & 42.5 & 1.95 & $1.46-2.61$ & \\
\hline Skin color & & & & & & 0.346 \\
\hline White & 815 & 74.3 & 32.3 & - & - & \\
\hline Not white & 281 & 24.7 & 35.3 & 1.09 & $0.90-1.31$ & \\
\hline Marital status & & & & & & 0.002 \\
\hline Single & 223 & 20.4 & 15.5 & - & - & \\
\hline Married + union & 700 & 63.8 & 64.6 & 1.34 & $1.04-1.72$ & \\
\hline Divorced + widow & 173 & 15.8 & 19.9 & 1.66 & $1.24-2.21$ & \\
\hline Education (years) & & & & & & $<0.001$ \\
\hline$\geq 11$ & 455 & 41.5 & 32.7 & - & - & \\
\hline $8-10$ & 196 & 17.9 & 18.6 & 1.36 & $0.89-2.06$ & \\
\hline $5-7$ & 247 & 22.6 & 26.0 & 1.67 & $1.09-2.57$ & \\
\hline $0-4$ & 198 & 18.0 & 22.7 & 1.94 & $1.30-2.89$ & \\
\hline Family income (BRL) & & & & & & 0.024 \\
\hline 1 st tertile $(\leq 190.71)$ & 352 & 33.3 & 35.8 & 1.28 & $1.03-1.59$ & \\
\hline $2^{\text {nd }}$ tertile (190.72-345.81) & 348 & 32.9 & 35.8 & 1.29 & $1.04-1.61$ & \\
\hline 3rd tertile ( $\geq 345.82$ ) & 358 & 33.8 & 28.4 & - & - & \\
\hline Employed & & & & & & 0.042 \\
\hline Yes & 614 & 56.1 & 30.6 & - & - & \\
\hline No & 482 & 43.9 & 36.4 & 1.19 & $1.00-1.40$ & \\
\hline Transport used to purchase foods & & & & & & 0.88 \\
\hline On foot/Bicycle & 442 & 40.3 & 40.6 & - & - & \\
\hline Car/Moto/Bus & 654 & 59.7 & 59.4 & 0.98 & $0.83-1.17$ & \\
\hline \multicolumn{7}{|l|}{ Nutritional status } \\
\hline Normal & 371 & 33.9 & & & & \\
\hline Overweight & 361 & 33.0 & & & & \\
\hline \multirow[t]{2}{*}{ Obesity } & 362 & 33.1 & & & & \\
\hline & Mean & SD & & PR & $95 \% \mathrm{Cl}$ & p-value \\
\hline Fruits and vegetables (consume/day) & 6.34 & 2,90 & & 1.03 & $1.00-1.06$ & 0.013 \\
\hline Sweet drink (consume/day) & 0.46 & 0.40 & & 1.15 & $0.93-1.41$ & 0.175 \\
\hline Number of stores * & 1.69 & 0.70 & & 1.15 & $1.04-1.27$ & 0.005 \\
\hline $\begin{array}{l}\text { Number of food items bought inside } \\
\text { the neighborhood ** }\end{array}$ & 4.18 & 3.52 & & 0.99 & $0.97-1.01$ & 0.58 \\
\hline
\end{tabular}

95\%Cl: 95\% confidence interval; PR: prevalence ratio; SD: standard deviation.

* Number of types of establishment that women access;

** Number of items that women buy inside their neighborhood.

worked at the time of the interview (56.1\%). In relation to food intake, they consumed on average 6.34 (SD: 2.90) fruits and vegetables per day, and drank sugar drinks 0.46 (SD: 0.40) times per day. In relation to food purchases, women reported accessing an average of 1.69 (SD: 0.70) types of food establishments, relying on their neighborhood to purchase, on average, 4.18 (SD: 3.52) food items 
out of the 8 enquired, and $59.7 \%$ of women reported making the majority of their purchases by car, motorcycle or bus (Table 1).

The prevalence of obesity in the sample was $33.1 \%$. Table 1 shows the crude prevalence ratios for obesity with the characteristics of the sample. Compared to their respective reference category, a higher obesity prevalence was found in the higher age groups ( $P R=1.95$; 95\%CI: 1.46-2.61), among those divorced, separated and widowed ( $\mathrm{PR}=1.66$; 95\%CI: 1.24-2.21), those with a lower schooling level (PR = 1.94; 95\%CI: 1.30-2.89) and in the second tertile level of income (PR = 1.29; 95\%CI: $1.04-$ 1.61), as well as among women who were not working ( $\mathrm{PR}=1.19 ; 95 \% \mathrm{CI}$ : 1.00-1.40). The frequency of consumption of fruits and vegetables and the number of stores accessed by women to purchase food were associated with obesity, with PRs of 1.03 (95\%CI: 1.00-1.06; p = 0.013) and 1.15 (95\%CI: 1.04-1.27; $\mathrm{p}=0.005)$, respectively.

Concerning the food environment, 279 food stores were identified, of which 95 were supermarkets (34.1\%), 95 grocery stores (34.1\%), 17 (6.1\%) convenience stores, 37 (13.3\%) bakeries, 11 (3.9\%) butchers, 19 (6.8\%) fruit producers and 5 (1.8\%) others (data not shown).

Table 2 shows the relationship between environmental-level variables (availability of four different types of food establishments and income) and obesity. The associations were not substantially different when using absolute compared to relative measures. Results for absolute measures are presented here, while those for relative measures can be found in the Supplementary Material (http:// cadernos.ensp.fiocruz.br/site/public_site/arquivo/supl-e00144618_6899.pdf). In the crude analysis, women living in neighborhoods where supermarkets were available presented a $6 \%$ higher prevalence of obesity, when compared to those without this food establishment in their neighborhood ( $\mathrm{PR}=1.06$; 95\%CI: 1.01-1.10). After controlling for individual variables (age, marital status, family income, education, employment, consumption of fruits and vegetables and food purchasing behaviors), the association between supermarket exposure and obesity was maintained (PR = 1.05; 95\%CI: 1.01-1.10). The direction of the association between availability of healthy establishments in the neighborhood and obesity was the same. After adjusting for demographic, socioeconomic, food intake and food purchase variables, obesity and healthy establishments were associated (PR = 1.02; 95\%CI: 1.00-1.04). There was an inverse association between the mean income of the buffer and obesity, meaning that the higher the neighborhood-level income, the lower the prevalence of obesity, even after adjusting for potential confounders. A 36\% lower prevalence of obesity was observed in women living in areas with a higher mean income, when compared to those living in more disadvantaged areas. (Table 2). Grocery stores and convenience stores were not associated with obesity in the multilevel Poisson regression analysis.

Table 3 shows the mean number of each type of food store for the full analytical sample and stratified by individual-level income tertile. The highest mean was found for healthy establishments (6.44; SD: 0.83), followed by supermarkets (2.98; SD: 5.41), grocery stores (2.57; SD: 2.89), and convenience stores (0.33; SD: 0.67). As income tertiles increased, there was an increase in the mean number of convenience stores.

Table 3 also shows results for the assessment of the interaction between type of food store and individual-level income (in tertiles). There was a significant interaction for the 1st tertile (lowest income) with supermarket and healthy stores, that low income women with access to these stores had a $7 \%$ and $2 \%$ higher obesity risk compared to those without access (PR = 1.07; 95\%CI: 1.03-1.12 and $\mathrm{PR}=1.02$; 95\%CI: 1.00-1.05, respectively). A significant interaction was also found among women in the 3rd income tertile but for supermarkets only (PR = 1.03; 95\%CI: 1.00-1.07).

\section{Discussion}

We explored the association between the characteristics of the food environment and obesity in women living in a midsize Brazilian city, thus contributing to the literature on neighborhood effects on obesity in a middle-income country. We found that obesity was positively associated with the availability of supermarket and healthy food establishments in the neighborhood and inversely associated with the average income of the neighborhood. 
Table 2

Multilevel Poisson regression models for the association between the neighborhood food environment and obesity ( $n=1$,096). São Leopoldo, Rio Grande do Sul State, Brazil, 2015.

\begin{tabular}{|c|c|c|c|c|c|c|c|c|c|c|}
\hline \multirow[t]{2}{*}{ Variable } & \multicolumn{2}{|c|}{ Supermarket } & \multicolumn{2}{|c|}{ Grocery store } & \multicolumn{2}{|c|}{ Convenience store } & \multicolumn{2}{|c|}{ Healthy store * } & \multicolumn{2}{|c|}{ Mean income ** } \\
\hline & PR & $95 \% \mathrm{Cl}$ & PR & $95 \% \mathrm{Cl}$ & PR & $95 \% \mathrm{Cl}$ & PR & $95 \% \mathrm{Cl}$ & PR & $95 \% \mathrm{Cl}$ \\
\hline Crude & 1.06 & $1.01-1.10 * * *$ & 1.01 & $0.98-1.05$ & 0.86 & $0.72-1.03$ & 1.02 & $1.00-1.04$ \# & 0.64 & $0.49-0.84 * * *$ \\
\hline Model 1 & 1.05 & $1.01-1.10 * \star *$ & - & - & - & - & - & - & - & - \\
\hline Model 2 & - & - & 1.0 & $0.97-1.04$ & - & - & - & - & - & - \\
\hline Model 3 & - & - & - & - & 0.86 & $0.72-1.02$ & - & - & - & - \\
\hline Model 4 & - & - & - & - & - & - & 1.02 & $1.00-1.04$ \# & - & - \\
\hline Model 5 & - & - & - & - & - & - & - & - & 0.64 & $0.49-0.83 * * *$ \\
\hline
\end{tabular}

95\% Cl: 95\% confidence interval; PR: prevalence ratio.

Note: Crude: effect of the types of foods stores without ajustment; Model 1: supermarket controlling for individual variables (age, marital status, family income, education, employment, consumption of fruits and vegetables and food purchasing behaviors); Model 2: grocery store controlling for individual variables; Model 3: convenience store controlling for individual variables; Model 4: healthy store controlling for individual variables; Model 5: mean income controlling for individual variables.

* Stores with more healthy and intermediate items than unhealthy items, from Nutrition Environment Measure - Stores (NEMS);

** Total monthly income of individuals 10 years of age or older (Brazilian Institute of Geography and Statistics) within the buffer divided by 1,000 ;

$\star * * \mathrm{p}<0.01$;

$\# p<0.05$.

\section{Table 3}

Descriptive statistics for the neighborhood food environment, full sample and by family income (individual variable) and the association between availability of specific types of food establishments and obesity, stratified by family income.

\begin{tabular}{|c|c|c|c|c|c|c|c|c|}
\hline \multirow[t]{2}{*}{ Variable } & \multicolumn{2}{|c|}{ Total } & \multicolumn{2}{|c|}{ 1st tertile ( $\leq$ BRL 190.71) } & \multicolumn{2}{|c|}{ 2nd tertile (BRL 190.72-345.81) } & \multicolumn{2}{|c|}{ 3rd tertile ( $\geq$ BRL 345.82) } \\
\hline & Mean & SD & Mean & SD & Mean & SD & Mean & SD \\
\hline Supermarket & 2.98 & 5.41 & 3,28 & 2,47 & 3.13 & 2.47 & 2.55 & 2.28 \\
\hline Convenience store & 0.33 & 0.67 & 0.21 & 0.49 & 0.24 & 0.47 & 0.53 & 0.90 \\
\hline Grocery store & 2.57 & 2.89 & 3.02 & 3.23 & 2.74 & 3.10 & 1.98 & 2.12 \\
\hline \multirow[t]{2}{*}{ Healthy stores * } & 6.44 & 0.83 & 6.90 & 4.83 & 6.65 & 4.71 & 5.83 & 4.28 \\
\hline & & & PR & $95 \% \mathrm{Cl}$ & PR & $95 \% \mathrm{Cl}$ & PR & $195 \% \mathrm{Cl}$ \\
\hline Supermarket & & & 1.07 & $1.03-1.12$ ** & 1.06 & $1.02-1.11 * * *$ & 1.03 & $1.00-1.07 \#$ \\
\hline Convenience store & & & 0.88 & $0.74-1.05$ & 0.85 & $0.71-1.02$ & 0.95 & $0.77-1.16$ \\
\hline Grocery store & & & 1.01 & $0.97-1.04$ & 1.03 & $1.00-1.06 \#$ & 1.00 & $0.97-1.03$ \\
\hline Healthy stores * & & & 1.02 & $1.00-1.05 * * *$ & 1.02 & $1.00-1.05 * * *$ & 1.01 & $0.99-1.03$ \\
\hline
\end{tabular}

95\%Cl: 95\% confidence interval; PR: prevalence ratio; SD: standard deviation.

Note: Poisson analysis. The interaction between type of food store and income was tested before the Poisson analysis and all presented $\mathrm{p}<0.05$.

* Stores with more healthy and intermediate items than unhealthy items, from Nutrition Environment Measure - Stores (NEMS);

** $\mathrm{p}<0.001$;

*** $\mathrm{p}<0.01$;

$\# \mathrm{p}<0.05$. 
This is consistent with the literature which shows that contextual characteristics are associated with obesity in men and women 1, however, no studies have been found that highlight the relationship between food environment and obesity in women specifically. Importantly, in our study $76 \%$ of the women interviewed were responsible for purchasing food in their homes, and this reinforces the importance of studying the relationship between the food environment and obesity among women since they are responsible for making purchasing decisions in their households. The obesity prevalence of $33.1 \%$ among participating women, as well as obesity being positively associated with age and inversely related to family income and schooling are in line with previous research 7,9,10,11,58. One of the possible explanations for the relationship between the neighborhood and obesity, especially in poor economic communities, is due to the high exposure to unhealthy foods and limited access to healthy foods 59 . Although economically disadvantaged populations have a good density of establishments 60,61 , the quality of the foods provided may inhibit a healthy eating behavior among the residents who depend on this trade 62 . Evidence suggests that the neighborhood socioeconomic status, both in developing and developed countries, can influence the health of individuals and still affect many of the factors associated with the prevalence of obesity by environmental factors, such as access to healthy food stores, healthy restaurants, places for physical activity and parks, and price and availability of healthy food 29,38,42,58,63,64,65.

We hypothesized that being exposed to a supermarket would reduce the prevalence of obesity, since women would have greater diversity in choice and thus greater opportunities for buying healthy foods, but our findings did not support this hypothesis. In our study supermarket availability was positively associated with obesity, whereas the majority of previous research, which was conducted in different social contexts, for it occurred in developing countries, has reported an inverse relationship 18,25,29. However, two previous studies reported results similar to ours. In one study, the relationship between obesity and living in a "food desert" (i.e., areas without healthy foods available), in adults in Detroit (United States), Budzynska et al. 66, found that people who shopped at supermarkets had higher BMIs compared to those who bought groceries from other food stores. Similarly, Chaparro et al. 67 found that in Los Angeles (United States), residents who had a supermarket in their neighborhood had twice the risk of being obese when compared to those without supermarket access $(\mathrm{OR}=2.02$; 95\%CI: 1.44-2.83), however, the neighborhood density of unhealthy food outlets did not modify this association. One possible explanation for this association is that supermarkets sell different types of foods, both healthy and unhealthy, and that the proportion of the latter to the former is often higher 67,68. In addition ultraprocessed foods of low nutritional quality are usually less expensive than fresh healthy foods, so although both can be bought in supermarkets, cheaper foods might be more popular $36,68,69,70$.

We also found that obesity was positively associated with the access to a healthy food establishment. This relationship needs to be studied in more depth, but one avenue of research might be to understand if the price of healthy food is one of the possible factors that explains this result. There is evidence suggesting that healthier diets tend to be more expensive and that when food prices increase, the quality of diet decreases $68,71,72$. Making healthy foods cheaper is one way to encourage people to buy these foods, and this is only possible through monetary policies. A promising way to improve food intake is through food taxation 73 . This is already evident in the scientific literature, demonstrating that both subsidies and taxes influence food purchasing behaviors, and consequently, food intake, but none of the evidence is from Brazil specifically 74,75

In this study we used the NEMS score to classify food establishments. In the literature different measurement methods can be used to evaluate the food environment, both at the community level, through the location and density of food retailers, as well as at the consumer level, to assess in-store food availability, variety, price, and quality and to qualify stores as healthy or unhealthy 76 . In one study on adults from Philadelphia (United States), that has used the same method to describe the food environment, people were more likely to shop at food stores closest to home if the store had higher NEM-S scores, and to travel for shopping if stores had lower scores 62. Many studies, however, classify the environment into healthy or unhealthy based on commercial classifications only, such by categorizing "supermarkets" as "healthy stores" 25,77 . This classification presents limitations, and one is that stores usually offers both healthy and unhealthy foods 36 . A combination of methodologies as 
we used here may enable a more comprehensive assessment of the relationship between the environment and obesity 30 .

The results of the present study should be interpreted in light of methodological limitations. First, the cross-sectional design does not allow to establish causal relationships and reverse causality cannot be excluded. For example, an unfavorable food environment could lead to a behavioral change that would influence obesity, but, on the other hand, it is possible that the food environment would have adapted to the demand of obese customers. Considering the current Brazilian food policy, a second limitation is the classification of establishments according to the NEMS classification which considers the nutritional composition of foods but not the level of industrial processing, which is being recognized as an important determinant of health 78,79 . The third limitation is our focus on the residential neighborhood since women can buy food near their workplace or travel to shop in different areas. This is especially important considering that participants reported buying only half of the staple items in establishments located in what they considered to be their neighborhood. Finally, the timeframe for assessing food intake (i.e., 3 months prior to interview), differs from the 12-month period often used in other studies. Nonetheless, the timeframe chosen was consistent with timing of food environment.

Worldwide, changes in the political landscape related to nutrition are occurring, with an increasing number of countries taking regulatory action to improve the food environment to promote healthy and quality foods and Brazil is no different. Important public policies have been proposed, including some that acknowledge that the environment can benefit the population's health by reinforcing the contextual approach to obesity prevention and promoting healthy eating 80,81,82,83.

This paper adds to the literature from elsewhere that suggests residential neighborhood may be an important contextual factor for obesity but that understanding it properly, and within countryspecific settings, is likely to be an important part of ensuring that obesity prevention strategies are effective.

\section{Contributors}

V. Backes and M. T. A. Olinto contributed to the data collection, data analysis, and writing. F. Bairros and C. B. Cafruni contributed to the data collection. S. Cummins, M. Shareck, and K. Mason contributed to the data analysis and writing. J. S. Dias-da-Costa cotnributed to the data collection and data analysis.

\section{Additional informations}

ORCID: Vanessa Backes (0000-0002-3860-7866); Fernanda Bairros (0000-0002-8611-058X); Cristina Borges Cafruni (0000-0002-3568-0785); Steven Cummins (0000-0002-3957-4357); Martine Shareck (0000-0001-9162-3374); Kate Mason (0000-0001-5020-5256); Juvenal Soares Dias-daCosta (0000-0003-3160-6075); Maria Teresa Anselmo Olinto (0000-0002-3950-4594).

\section{Acknowledgments}

To the Brazilian Graduation Studies Coordinating Board (Capes) and the Brazilian National Research Council (CNPq) for the funding of the research project and the sandwich scholarship of one of its authors (MCTI/CNPQ/Universal 14/2014; Capes/ PSDE n. 19/2016; MTAO; CNPQ/PQ, n. 307257/213-4). 


\section{References}

1. NCD Risk Factor Collaboration. Trends in adult body-mass index in 200 countries from 1975 to 2014: a pooled analysis of 1698 population-based measurement studies with 19.2 million participants. Lancet 2016; 387:137796.

2. Glanz K, Bishop DB. The role of behavioral science theory in development and implementation of public health interventions. Annu Rev Public Health 2010; 31:399-418.

3. Hammond RA. Complex systems modeling for obesity research. Prev Chronic Dis 2009; 6:A97.

4. Kamphuis CB, Giskes K, de Bruijn GJ, WendelVos W, Brug J, Van Lenthe FJ. Environmental determinants of fruit and vegetable consumption among adults: a systematic review. $\mathrm{Br} \mathrm{J}$ Nutr 2006; 96:620-35.

5. Lopez RP. Neighborhood risk factors for obesity. Obesity (Silver Spring) 2007; 15:2111-9.

6. Swinburn B, Egger G, Raza F. Dissecting obesogenic environments: the development and application of a framework for identifying and prioritizing environmental interventions for obesity. Prev Med 1999; 29(6 Pt 1):563-70.

7. Swinburn BA, Sacks G, Hall KD, McPherson K, Finegood DT, Moodie ML, et al. The global obesity pandemic: shaped by global drivers and local environments. Lancet 2011; 378:804-14.

8. Sallis JF, Glanz K. Physical activity and food environments: solutions to the obesity epidemic. Milbank Q 2009; 87:123-54.

9. Backes V, Olinto MT, Henn RL, Cremonese C, Pattussi MP. Associação entre aspectos psicossociais e excesso de peso referido em adultos de um município de médio porte do Sul do Brasil. Cad Saúde Pública 2011; 27:573-80.

10. Dubowitz T, Ghosh-Dastidar M, Eibner C, Slaughter ME, Fernandes M, Whitsel EA, et al. The women's health initiative: the food environment, neighborhood socioeconomic status, BMI, and blood pressure. Obesity (Silver Spring) 2012; 20:862-71 .

11. Siddiquee T, Bhowmik B, Da Vale Moreira NC, Mujumder A, Mahtab H, Khan AK, et al. Prevalence of obesity in a rural Asian Indian (Bangladeshi) population and its determinants. BMC Public Health 2015; 15:860.

12. Correia LL, Silveira DMI, Silva AC, Campos JS, Machado MMT, Rocha HAL, et al. Prevalência e determinantes de obesidade e sobrepeso em mulheres em idade reprodutiva residentes na região semiárida do Brasil. Ciênc Saúde Colet 2011; 16:133-45.

13. Teichmann L, Olinto MTA, Costa JSD, Ziegler D. Fatores de risco associados ao sobrepeso e obesidade em mulheres de São Leopoldo, RS. Rev Bras Epidemiol 2006; 9:360-73.

14. Simões BS, Cardoso LO, Benseñor IJM, Schmidt MI, Duncan BB, Luft VC, et al. Consumption of ultra-processed foods and socioeconomic position: a cross-sectional analysis of the Brazilian Longitudinal Study of Adult Health. Cad Saúde Pública 2018; 34:e00019717.
15. Swinburn B, Dominick CH, Vandevijvere S Benchmarking food environments: experts' assessments of policy gaps and priorities for the New Zealand Government. Auckland: University of Auckland; 2014.

16. Almeida LB, Scagliusi FB, Duran AC, Jaime PC. Barriers to and facilitators of ultra-processed food consumption: perceptions of Brazilian adults. Public Health Nutr 2018; 21:68-76.

17. Boutelle KN, Murray DM, Jeffery RW, Hennrikus DJ, Lando HA. Associations between exercise and health behaviors in a community sample of working adults. Prev Med 2000; 30:217-24

18. Caspi CE, Sorensen G, Subramanian SV, Kawachi I. The local food environment and diet: a systematic review. Health Place 2012; 18:1172-87.

19. Hawkes C. Sales promotions and food consumption. Nutr Rev 2009; 67:333-42.

20. U.S. Department of Agriculture. Economic Research Service (ERS). Washington DC: U.S. Department of Agriculture; 2013.

21. White M. Food access and obesity. Obes Rev 2007; 8 Suppl 1:99-107.

22. Leite FHM, de Carvalho Cremm E, de Abreu DSC, Oliveira MA, Budd N, Martins PA. Association of neighbourhood food availability with the consumption of processed and ultraprocessed food products by children in a city of Brazil: a multilevel analysis. Public Health Nutr 2018; 21:189-200.

23. Scarborough $\mathrm{P}$, Bhatnagar $\mathrm{P}$, Wickramasinghe KK, Allender S, Foster C, Rayner M. The economic burden of ill health due to diet, physical inactivity, smoking, alcohol and obesity in the UK: an update to 2006-07 NHS costs. J Public Health (Oxf) 2011; 33:527-35.

24. Wang YC, McPherson K, Marsh T, Gortmaker SL, Brown M. Health and economic burden of the projected obesity trends in the USA and the UK. Lancet 2011; 378:815-25.

25. Michimi A, Wimberly MC. The food environment and adult obesity in US metropolitan areas. Geospat Health 2015; 10:368.

26. Zenk SN, Mentz G, Schulz AJ, Johnson-Lawrence V, Gaines CR. Longitudinal associations between observed and perceived neighborhood food availability and body mass index in a multiethnic urban samples. Health Educ Behav 2017; 44:41-51.

27. Cobb LK, Appel LJ, Franco M, Jones-Smith JC, Nur A, Anderson CA. The relationship of the local food environment with obesity: a systematic review of methods, study quality, and results. Obesity (Silver Spring) 2015; 23:133144.

28. Matozinhos FP, Gomes CS, Andrade AC, Mendes LL, Pessoa MC, Friche AA, et al. Neighbourhood environments and obesity among adults: a multilevel analysis of an urban Brazilian context. Prev Med Rep 2015; 2:33741. 
29. Bodor JN, Rice JC, Farley TA, Swalm CM, Rose D. Disparities in food access: does aggregate availability of key foods from other stores offset the relative lack of supermarkets in African-American neighborhoods? Prev Med 2010; 51:63-7.

30. Duran AC, Diez Roux AV, Latorre MR, Jaime PC. Neighborhood socioeconomic characteristics and differences in the availability of healthy food stores and restaurants in São Paulo, Brazil. Health Place 2013; 23:39-47.

31. Franco M, Diez Roux AV, Glass TA, Caballero B, Brancati FL. Neighborhood characteristics and availability of healthy foods in Baltimore. Am J Prev Med 2008; 35:561-7.

32. Giskes K, Van Lenthe F, Avendano-Pabon M, Brug J. A systematic review of environmental factors and obesogenic dietary intakes among adults: are we getting closer to understanding obesogenic environments? Obes Rev 2011; 12:e95-e106.

33. Kerr J, Frank L, Sallis JF, Saelens B, Glanz K, Chapman J. Predictors of trips to food destinations. Int J Behav Nutr Phys Act 2012; 9:58.

34. Assis MM, Leite MA, Carmo ASD, Andrade ACS, Pessoa MC, Netto MP, et al. Food environment, social deprivation and obesity among students from Brazilian public schools. Public Health Nutr 2019; 22:1920-7.

35. Menezes MC, Costa BV, Oliveira CD, Lopes AC. Local food environment and fruit and vegetable consumption: an ecological study. Prev Med Rep 2016; 5:13-20.

36. Minaker LM, Shuh A, Olstad DL, EnglerStringer R, Black JL, Mah CL. Retail food environments research in Canada: a scoping review. Can J Public Health 2016; 107 Suppl $1: 5344$.

37. Morland KB, Evenson KR. Obesity prevalence and the local food environment. Health Place 2009; 15:491-5.

38. Corrêa EN, Rossi CE, das Neves J, Silva DAS, de Vasconcelos FAG. Utilization and environmental availability of food outlets and overweight/obesity among schoolchildren in a city in the south of Brazil. J Public Health (Oxf) 2018; 40:106-13.

39. Feng J, Glass TA, Curriero FC, Stewart WF, Schwartz BS. The built environment and obesity: a systematic review of the epidemiologic evidence. Health Place 2010; 16:175-90.

40. Fuller D, Cummins S, Matthews SA. Does transportation mode modify associations between distance to food store, fruit and vegetable consumption, and BMI in low-income neighborhoods? Am J Clin Nutr 2013; 97:167-72.

41. Gamba RJ, Schuchter J, Rutt C, Seto EY. Measuring the food environment and its effects on obesity in the United States: a systematic review of methods and results. J Community Health 2015; 40:464-75.

42. Jaime PC, Duran AC, Sarti FM, Lock K. Investigating environmental determinants of diet, physical activity, and overweight among adults in Sao Paulo, Brazil. J Urban Health 2011; 88:567-81.
43. Mendes LL, Nogueira H, Padez C, Ferrao M, Velasquez-Melendez G. Individual and environmental factors associated for overweight in urban population of Brazil. BMC Public Health 2013; 13:988.

44. Instituto Brasileiro de Geografia e Estatística. Pesquisa de Orçamentos Familiares, 20082009: avaliação nutricional da disponibilidade domiciliar de alimentos no Brasil. Rio de Janeiro: Instituto Brasileiro de Geografia e Estatística; 2010.

45. Diez J, Bilal U, Cebrecos A, Buczynski A, Lawrence RS, Glass T, et al. Understanding differences in the local food environment across countries: a case study in Madrid (Spain) and Baltimore (USA). Prev Med 2016; 89:237-44.

46. Drewnowski A, Aggarwal A, Tang W, Hurvitz PM, Scully J, Stewart O, et al. Obesity, diet quality, physical activity, and the built environment: the need for behavioral pathways. BMC Public Health 2016; 16:1153.

47. Hobbs M, Green M, Griffiths C, Jordan H, Saunders J, McKenna J. How different data sources and definitions of neighbourhood influence the association between food outlet availability and body mass index: a crosssectional study. Perspect Public Health 2017; 137:158-61.

48. McInerney M, Csizmadi I, Friedenreich CM, Uribe FA, Nettel-Aguirre A, McLaren L, et al. Associations between the neighbourhood food environment, neighbourhood socioeconomic status, and diet quality: an observational study. BMC Public Health 2016; 16:984.

49. Brownson RC, Hoehner CM, Day K, Forsyth A, Sallis JF. Measuring the built environment for physical activity: state of the science. Am J Prev Med 2009; 36 Suppl 4:S99-123.

50. Glanz K, Sallis JF, Saelens BE, Frank LD. Nutrition Environment Measures Survey in stores (NEMS-S): development and evaluation. Am J Prev Med 2007; 32:282-9.

51. Martins PA, Cremm EC, Leite FH, Maron LR, Scagliusi FB, Oliveira MA. Validation of an adapted version of the nutrition environment measurement tool for stores (NEMS-S) in an urban area of Brazil. J Nutr Educ Behav 2013; 45:785-92.

52. Organização Mundial da Saúde. Obesidade: prevenindo e controlando a epidemia global. São Paulo: Roca; 2004.

53. Bonatto S, Henn RL, Olinto MT, Anjos LA, Wahrlich V, Waissmann W. Reprodutibilidade, validade relativa e calibração de um questionário de frequência alimentar para adultos da Região Metropolitana de Porto Alegre, Rio Grande do Sul, Brasil. Cad Saúde Pública 2014; 30:1837-48.

54. Willet WC. Nutritional epidemiology. Oxford: Oxford University Press; 1998.

55. Chow CK, Lock K, Madhavan M, Corsi DJ, Gilmore AB, Subramanian SV, et al. Environmental Profile of a Community's Health (EP$\mathrm{OCH})$ : an instrument to measure environmental determinants of cardiovascular health in five countries. PLoS One 2010; 5:e14294. 
56. Puente-Palacios KE, Laros JA. Análise multinível: contribuições para estudos sobre efeito do contexto social no comportamento individual. Estud Psicol 2009; 26:349-61.

57. McNutt LA, Wu C, Xue X, Hafner JP. Estimating the relative risk in cohort studies and clinical trials of common outcomes. Am J Epidemiol 2003; 157:940-3.

58. Stafford M, Brunner EJ, Head J, Ross NA. Deprivation and the development of obesity a multilevel, longitudinal study in England. Am J Prev Med 2010; 39:130-9.

59. Hilmers A, Hilmers DC, Dave J. Neighborhood disparities in access to healthy foods and their effects on environmental justice. Am J Public Health 2012; 102:1644-54.

60. Cummins S, Macintyre S. The location of food stores in urban areas: a case study in Glasgow. Br Food J 1999; 101:545-53.

61. Lamichhane AP, Warren JL, Peterson M, Rummo P, Gordon-Larsen P. Spatial-temporal modeling of neighborhood sociodemographic characteristics and food stores. Am J Epidemiol 2015; 181:137-50.

62. Cannuscio CC, Tappe K, Hillier A, Buttenheim A, Karpyn A, Glanz K. Urban food environments and residents' shopping behaviors. Am J Prev Med 2013; 45:606-14.

63. High Level Panel of Experts on Food Security and Nutrition. Nutrition and food systems. Rome: High Level Panel of Experts on Food Security and Nutrition; 2017.

64. Monteiro CA, Moura EC, Conde WL, Popkin BM. Socioeconomic status and obesity in adult populations of developing countries: a review. Bull World Health Organ 2004; 82:940-6.

65. Wang MC, Kim S, Gonzalez AA, MacLeod KE, Winkleby MA. Socioeconomic and food-related physical characteristics of the neighbourhood environment are associated with body mass index. J Epidemiol Community Health 2007; 61:491-8.

66. Budzynska K, West P, Savoy-Moore RT, Lindsey D, Winter M, Newby PK. A food desert in Detroit: associations with food shopping and eating behaviours, dietary intakes and obesity. Public Health Nutr 2013; 16:2114-23.

67. Chaparro MP, Harrison GG, Wang MC, Seto EY, Pebley AR. The unhealthy food environment does not modify the association between obesity and participation in the Supplemental Nutrition Assistance Program (SNAP) in Los Angeles County. BMC Public Health 2017; 17:81.

68. Machado PP, Claro RM, Martins APB, Costa JC, Levy RB. Is food store type associated with the consumption of ultra-processed food and drink products in Brazil? Public Health Nutr 2018; 21:201-9.

69. Leete L, Bania N, Sparks-Ibanga A. Congruence and coverage alternative approaches to identifying urban food deserts and food hinterlands. J Plan Educ Res 2011; 32:204-18.

70. Shier V, An R, Sturm R. Is there a robust relationship between neighbourhood food environment and childhood obesity in the USA? Public Health 2012; 126:723-30.
71. Claro RM, Maia EG, Costa BV, Diniz DP. Preço dos alimentos no Brasil: prefira preparações culinárias a alimentos ultraprocessados. Cad Saúde Pública 2016; 32:e00104715.

72. Rao M, Afshin A, Singh G, Mozaffarian D. Do healthier foods and diet patterns cost more than less healthy options? A systematic review and meta-analysis. BMJ Open 2013; 3:e004277.

73. World Health Organization. Global status report on noncommunicable diseases 2014. Geneva: World Health Organization; 2014.

74. Eyles H, Ni Mhurchu C, Nghiem N, Blakely T. Food pricing strategies, population diets, and non-communicable disease: a systematic review of simulation studies. PLoS Med 2012; 9:e1001353.

75. Thow AM, Annan R, Mensah L, Chowdhury SN. Development, implementation and outcome of standards to restrict fatty meat in the food supply and prevent NCDs: learning from an innovative trade/food policy in Ghana. BMC Public Health 2014; 14:249.

76. Glanz K, Sallis JF, Saelens BE, Frank LD. Healthy nutrition environments: concepts and measures. Am J Health Promot 2005; 19:330-3, ii.

77. Hosler AS, Michaels IH, Buckenmeyer EM Food shopping venues, neighborhood food environment, and body mass index among Guyanese, black and white adults in an urban community in the US. J Nutr Educ Behav 2016; 48:361-8.

78. Monteiro CA, Levy RB, Claro RM, de Castro IR, Cannon G. Increasing consumption of ultra-processed foods and likely impact on human health: evidence from Brazil. Public Health Nutr 2011; 14:5-13.

79. Moubarac JC, Parra DC, Cannon G, Monteiro CA. Food classification systems based on food processing: significance and implications for policies and actions: a systematic literature review and assessment. Curr Obes Rep 2014; 3:256-72.

80. Ministério da Saúde. Guia alimentar para a população brasileira. 2a Ed. Brasília: Ministério da Saúde; 2014.

81. Ministério do Desenvolvimento Social e Combate à Fome. Estratégia intersetorial de prevenção e controle da obesidade: recomendações para estados e municípios. Brasília: Imprensa Nacional; 2014.

82. Câmara Interministerial de Segurança Alimentar e Nutricional. II Plano Nacional de Segurança Alimentar e Nutricional. Brasília: Câmara Interministerial de Segurança Alimentar e Nutricional; 2018.

83. World Health Organization. Global nutrition policy review 2016-2017: country progress in creating enabling policy environments for promoting healthy diets and nutrition. Geneva: World Health Organization; 2018. 


\section{Resumo}

O estudo teve como objetivo explorar as relações entre o ambiente alimentar da vizinhança e obesidade em mulheres na área urbana de São Leopoldo, Rio Grande do Sul, Brasil, através de um inquérito transversal. O estudo teve uma amostra de 1.096 mulheres. Foram realizadas entrevistas estruturadas com um questionário padronizado e previamente testado. A obesidade foi definida como indice de massa corporal (IMC) $\geq 30 \mathrm{~kg} / \mathrm{m}^{2}$. Foram criadas zonas-tampão com raio de $400 \mathrm{~m}$ em torno do centroide das residências das participantes nos 45 setores censitários. Os estabelecimentos varejistas com venda de alimentos na vizinhança foram identificados através de uma pesquisa sistemática das áreas do estudo, e foram coletadas as coordenadas geográficas dessas lojas. Os estabelecimentos foram avaliados com a ferramenta NEMS. A prevalência de obesidade foi 33\% entre as participantes. Depois de ajustar para as variáveis individuais, os supermercados e os estabelecimentos com alimentos saudáveis mostraram uma associação positiva com a obesidade, $R P=$ 1,05 (IC95\%: 1,01-1,10), RP = 1,02 (IC95\%: 1,001,04), respectivamente, enquanto que a renda média da zona-tampão mostrou associação negativa, $R P=0,64$ (IC95\%: 0,49-0,83). Os fatores de ambiente alimentar da vizinhança estiveram associados à obesidade, mesmo depois de controlar para as variáveis individuais, socioeconômicas, comportamentais e de compra de alimentos.

Alimentação; Obesidade; Mulheres

\section{Resumen}

El objetivo de este estudio fue investigar las relaciones entre el entorno alimentario del vecindario y la obesidad en mujeres que viven en áreas urbanas de São Leopoldo, Rio Grande do Sul, Brasil. Se llevó a cabo un estudio transversal. Este estudio se realizó con 1.096 mujeres. Se realizaron entrevistas estructuradas, usando un cuestionario estándar probado previamente. La obesidad se definió como un indice de masa corporal (IMC) $\geq 30 \mathrm{~kg} / \mathrm{m}^{2}$. Se crearon amortiguadores circulares en un radio de $400 m$, basados en el centroide de las casas de las mujeres que participaron, en los 45 distritos censales donde residian. Los establecimientos de comida del vecindario fueron identificados mediante un estudio sistemático de todas las calles en las áreas de estudio y también se recabaron las coordenadas geográficas de las tiendas. Los establecimientos fueron evaluados usando el instrumento NEMS. La prevalencia de obesidad fue de un 33\% entre las mujeres participantes. Tras el ajuste de las variables individuales, los supermercados y los establecimientos de comida sana estuvieron positivamente asociados con la obesidad, $R P=1,05$ (IC95\%: 1,01-1,10), RP = 1,02 (IC95\%: 1,00-1,04), respectivamente, mientras que un promedio de renta media estuvo negativamente asociado, $R P=$ 0,64 (IC95\%: 0,49-0,83). Los factores del vecindario en el entorno alimentario estuvieron asociados con la obesidad incluso después de ser controlados por variables individuales como: socioeconómicas, comportamentales y de compra de comida.

Alimentación; Obesidad; Mujeres
Submitted on $23 / \mathrm{Jul} / 2018$

Final version resubmitted on 28/Mar/2019

Approved on 02/Apr/2019 